\title{
EFFICIENCY OF DIFFERENT SCHEDULES OF POTASSIUM FOLIAR APPLICATION ON YIELD, YIELD COMPONENTS AND SOME PHYSIOCHEMICAL PROPERTIES OF HYBRID RICE UNDER SALINE SOIL CONDITIONS \\ Zayed, B. A.; W. H. M. El-Kallawy and R. N. Gorgy \\ Rice Research and Training Center, Sakha, 33717, Kafr EL-Shiekh, Field Crop Research Institute, Agriculture Research Center (ARC),Egypt.
}

\begin{abstract}
In order to overcome root media problems in feed application of Potassium under saline soil conditions, we carried out this investigation at El- Serw Agricultural Research Station, Agricultural Research Center, Egypt during 2009 and 2010 seasons in randomized complete plot design with four replication to study various schedules of potassium foliar sprays application with $2 \% \mathrm{~K}_{2} \mathrm{O}$ once at maximum tillering stage, twice at both maximum tillering growth and panicle initiation growth stages or thrice at maximum tillering growth, panicle initiation growth and booting growth stages along with root media application as basal with $\left(58 \mathrm{kgK}_{2} \mathrm{O} / \mathrm{ha}\right.$.) and control (without any application) on yield, yield components and some physiochemical properties of Egyptian hybrid Rice one( ERH 1 ) under saline soil conditions.

The results obtained revealed that potassium application either though root media as basal application or foliar sprays at different growth stages surpassed the control in all studied parameters. Foliar sprays of $\mathrm{K}$ with $2 \% \mathrm{~K}_{2} \mathrm{O}$ at different growth stages of rice plant showed significant superiority in plant height, number of panicles/ unit area, sterility \%, number of grains/ panicle, panicle weight, 1000 grain weight, grain yield and some of physiochemical parameters compared with potassium as basal application.

Among schedules of $\mathrm{K}$ foliar sprays application, data recorded that multi - way scheme of $\mathrm{K}$ foliar sprays application with $2 \% \mathrm{~K}_{2} \mathrm{O}$ at maximum tillering stage, panicle initiation stage and booting stage significantly produced the peak values in yield, yield components as well as physiochemical properties compared with the rest of $\mathrm{K}$ foliar sprays application under study.

Finally, from the data obtained it could be concluded that $\mathrm{K}$ foliar sprays with $2 \% \mathrm{~K}_{2} \mathrm{O}$ thrice at natal growth stages; maximum tillering stage, panicle initiation stage and booting stage is much sufficient to improve yield and yield components as well as physiochemical properties of Egyptian hybrid rice under saline soil conditions.

Keywords: Rice, potassium application, foliar, physiochemical properties
\end{abstract}

\section{INTRODUCTION}

Rice being one of the richest starchy foods and consumed by about half of the world's population. Rice is one of the most important summer cereal crops of Egypt and occupies second position after wheat. Environmental problems (e.g., water deficiency, salinity, high temperature, flooding, soil acidity, and pathogenic infections) are increasing as a results of increasing world population and intensive use of natural resources.

These a biotic stresses contribute significantly to reduce crop yields well below the potential maximum yields under standard conditions. Salinity 
is a stress to which rice is relatively sensitive as well as limited rice production under wide spectrum area. Under saline Egyptian soil conditions, some hybrids such SK2034H( Egyptian rice hybrid 1) was found to be more tolerant for salt and surpassed the rest hybrids and inbred in their growth, yield and its components (Zayed et al..,2007).

Mineral nutrient status of plants plays a critical role in increasing plant resistance of environmental stress factors (Marschner, 1995). Potassium is essential for many physiological process, such as photosynthesis, translocation of photosynthetic products, protein synthesis, control of ionic balance, regulation of plant stomata and water use as well as activation of plant enzymes (Marschner, 1995). Potassium is well known to activate at least sixty enzymes involved in plant growth. Potassium is also known as the quality nutrient because of its important effects on quality factors such as size, shape, color and other quality measurements.

Plants deficient in potassium are less resistance to salinity, drought, excess water and high and low temperature and potassium application was found to be effective under saline soil to enhance rice salinity tolerance, rice growth, yield and yield components (Qader, 1998 and Zayed et al. 2007). The indiscriminate and improper application with unfavorable conditions may not provide adequate nutrient supply of required fertilizer nutrients because of its poor absorption and translocation in plant system. Therefore, there is an imperative need to provide with required nutrients like potassium over and above the regular soil application through foliar nutrition practice. Such foliar application practice in rice is in vogue in the Philippines and other south east countries.

Foliar application of potassium is an efficient method of potassium supply to rice plants to avoid the interaction of both antagonistic and synergistic with essential major secondary and micro nutrients (Dibb and Thompson, 1985 ).

Zayed et al. 2006 and Gorgy et al. 2009 found that potassium split application at different critical growth stages of rice was found to be efficient in enhancing rice grain yield and yield components. Furthermore, Zayed, 2002, Wang et al.., 2004 and Bahmaniar, and Ranjbar (2007) stated that potassium application significantly increased rice grain yield, panicle characteristics and physiochemical properties of rice including cooking quality, chemical and milling ones.

Therefore, the present study was undertaken the effect of foliar schedules of potassium application a long with various plant growth stages as well as soil application on yield, yield components and some physiochemical prosperities of Egyptian rice hybrid one under saline soil conditions.

\section{MATERIALS AND METHODS}

The current trail was carried out at the Experimental Farm of El-Sirw Agriculture Research Station, Dammietta Governorate, at the northern part of Delta, Egypt in 2009 and 2010. The soil was clayey and the soil chemical properties are listed in Table 1. 
Table 1: Soil chemical properties at the experimental sites during 2009and 2010 seasons.

\begin{tabular}{|c|c|c|c|c|c|c|c|c|}
\hline \multirow{2}{*}{ Season } & \multirow{2}{*}{$\mathrm{pH}$} & \multirow{2}{*}{$\begin{array}{c}\text { EC } \\
\mathrm{dS} \mathrm{m}^{-1}\end{array}$} & \multicolumn{3}{|c|}{ Cation meq $\mathrm{L}^{-1}$} & \multicolumn{3}{|c|}{ Anion Meq L-1 } \\
\hline & & & $\mathrm{Ca}^{++}+\mathrm{Mg}^{++}$ & $\mathrm{Na}^{+}$ & $\mathrm{K}^{+}$ & $\mathrm{SO}_{4}$ & $\mathrm{Cl}^{-}$ & $\mathrm{HCO}_{3}^{-}$ \\
\hline 2009 & 8.3 & 5.3 & 29.0 & 54.0 & 0.32 & 48.5 & 29.3 & 8.0 \\
\hline 2010 & 8.2 & 5.0 & 28.0 & 48.0 & 0.31 & 30.0 & 38.0 & 7.0 \\
\hline \multicolumn{9}{|c|}{ Available nutrients $\mathbf{m g ~ k g}^{-1}$} \\
\hline & $\mathbf{N}$ & $\mathbf{P}$ & $\mathbf{K}$ & Zn & $\mathbf{S}$ & & $\mathrm{Fe}$ & $\mathrm{Cu}$ \\
\hline 2009 & 28.0 & 8.12 & 240.0 & 1.22 & 9.7 & & 5.00 & 6.2 \\
\hline 2010 & 26.0 & 8.35 & 200.0 & 1.16 & 9.5 & & 5.13 & 6.0 \\
\hline
\end{tabular}

The treatments studied the effect of different potassium foliar sprays with $2 \% \mathrm{~K}_{2} \mathrm{O}$ treatments once at maximum tillering stage or twice at maximum tillering and panicle initiation growth stages or thrice at maximum tillering, panicle initiation and booting growth stages and $\mathrm{K}$ applied as a basal application at the rate of $58 \mathrm{~kg} \mathrm{~K} \mathrm{~K}_{2} \mathrm{O} / \mathrm{ha}$, as well as control (without any application) on productivity, and grain physiochemical characteristics of Egyptian rice hybrid one (ERH1). The experiment was laid out in a randomized complete block design, with four replications. Single plant of 30 days old seedlings of Egyptian Rice Hybrid one (ERH1was transplanted/hill, spaced $20 \times 20 \mathrm{~cm}^{2}$ on May1, and harvested on September1. Nitrogen fertilizer was imposed in 4 equal doses 15 days after transplanting (DAT), mid-tillering stage, panicle initiation, and the end of booting stages as recommended under saline soil. All plots received $36 \mathrm{~kg} \mathrm{P}_{2} \mathrm{O}_{5} \mathrm{ha}^{-1}$. Plot area was $10 \mathrm{~m}^{2}$. At heading, ten hills from each plot were taken to estimate the dry mater.

At harvest, ten hills for each plot were counted to determine plant height $(\mathrm{cm})$ and number of panicles /hill was also measured. Ten main panicles from each subplot were packed to the laboratory to determine panicle length (cm), filled and unfilled grains/ panicle and 1000-grain weight.

Plants of the six inner rows of each subplot were harvested, dried, threshed, then grain and straw yields were determined at $14 \%$ moisture content and converted into t/ha.

\section{Grain quality traits:}

1. Grain shape: Grain dimension (length and width) were taken on 50 normal grains from each plot with help of a Micrometer. Length/width ratio (grain shape) was calculated from these values and the following scale as suggested by Khush et al.. (1979) was described the grain shape:

2. Hulling percentage:- About $150 \mathrm{~g}$ cleaned rough rice samples at moisture content $12-14 \%$ were estimated using experimental huller machine (satake) in Rice Research and Training Center, grain quality lab

3. Milling percentage:- Brown rice were consequently milled using McGILL Miller No.2 .The sample was milled for $60 \mathrm{sec}$.The milled rice sample was then collected and the weight was taken and percentage of total milled rice was computed

4. Head rice percentage: Whole grains were separated from the total milled rice using a rice sizing device. The separation of these particles is termed as grading. However, the broken are fragments of grains, which 
Zayed, B. A. et al.

the lengths are less than $3 / 4$ of the whole grains are after separated into two different sizes. The amount of head rice yield is then obtained and calculated

Cooking and eating quality characters:

Amylose content: It was estimated according to Juliano (1971).

Gross chemical composition of rice samples:

1- Moisture content (\%): Moisture content of rice samples was estimated using an air oven at $105 \pm 5^{\circ} \mathrm{C}$ until reaching a constant weight as given in the A.O.A.C.(1990)procedure.

2- Oil (\%): Total lipids of rice grains was extracted by ethyl ether using Soxhlet technique on dry basis as described by A.O.A.C.(1990).

3- Total protein content (\%): Total nitrogen content of rice was determined by using Microkjeldahl method outlined in the A.O.A.C. (1990).Crude protein content of the tested rice samples were calculated by multiplying the total nitrogen by the factor of 5.95 .

4- Ash content (\%): Ash content of rice grains was determined in an electric muffle at 525-550 $\cong \mathrm{C}$ until reaching the complete ashing following to the method described by A.O.A.C. (1990).

Statistical analysis:

All data collected were subjected to analysis of variance according to Gomez and Gomez (1984). Treatments means were compared by Duncan's multiple range test (Waller and Duncan, 1969). All statistical analysis was performed using variance technique by means of "MSTAT" computer soft war package.

\section{RESULTS AND DISCUSSION}

\section{Plant height $(\mathrm{cm})$ :}

Data presented in Table 2 revealed that highly significant differences were found among potassium foliar treatments in plant height at harvest in both studied seasons. The results obtained demonstrated that a semi fluctuation superiority among schedules of potassium application regards plant height compared with basal application and control where, foliar spray application of potassium nutrient with $2 \% \mathrm{~K}_{2} \mathrm{O}$ twice at maximum tillering stage and panicle formation stage significantly recorded the peak values of plant height $(98.1$ and $94.8 \mathrm{~cm}$ ) without any significant differences among the rest schedules of $\mathrm{K}$ foliar application in both studied seasons. These superiority of both ground or schedules of $\mathrm{K}$ foliar application over the control might be ascribed mainly to the role of potassium applied either ground or foliar a long with elongation period of rice plant. Liu et al.., 2003 reported that potassium deficiency stress decreased plant biomass, slow plant growth as well as retarded root growth.

\section{Number of panicles/ hill:}

Duncan's multiple range test showed highly significant differences among potassium foliar application and basal application with regards number of panicles /hill compared with the control in both seasons of study as shown in Table 2. It is evident from data obtained that potassium application either basal or foliar sprays at various growth stages significantly surpassed the control in regards to number of panicles/hill without any 
statistical differences among potassium application treatments in both seasons. Among potassium application treatments, $\mathrm{K}$ foliar sprays with $2 \%$ $\mathrm{K}_{2} \mathrm{O}$ application at maximum tillering stage produced the peak number of panicles/hill ( 17.5 and 17.9 ) followed by potassium as basal application with $58 \mathrm{~kg} \mathrm{~K} \mathrm{~K}_{2} \mathrm{O} / \mathrm{ha}$ ( 17.2 and 17.5 ) without any statistical differences among all $\mathrm{k}$ foliar sprays treatments which were on par in both seasons of study.

Ramos et al.., 1999 found that soil application of K plus $1 \% \mathrm{~K}$ sprayed twice at the end of tillering stage and panicle initiation stage resulted in the highest number of panicle per unit area. Yang et al.., 2005 asseverated also that rice roots greatly modify $\mathrm{K}$ mobility in the rhizosphere which ultimately enhances $\mathrm{K}$ uptake and increase tillering ability of rice plants. Similar finding has been reported by Gorgy et al.., 2009

Table 2: Plant height $(\mathrm{cm})$, number of panicles / hill, panicle length $(\mathrm{cm})$ and sterility (\%) as affected by Potassium foliar application nutrient at various physiological growth stages for ERH1 under saline soil conditions in 2009 and 2010 seasons.

\begin{tabular}{|c|c|c|c|c|c|c|c|c|}
\hline \multirow[t]{2}{*}{ Treatments } & \multicolumn{2}{|c|}{$\begin{array}{l}\text { Plant height } \\
(\mathbf{c m})\end{array}$} & \multicolumn{2}{|c|}{\begin{tabular}{|c} 
No. of Panicles \\
/hill
\end{tabular}} & \multicolumn{2}{|c|}{$\begin{array}{c}\text { Panicle length } \\
\text { cm }\end{array}$} & \multicolumn{2}{|c|}{$\begin{array}{c}\text { Sterility } \\
(\%)\end{array}$} \\
\hline & 2009 & 2010 & 2009 & 2010 & 2009 & 2010 & 2009 & 2010 \\
\hline & & $87.2 \mathrm{bc}$ & $13.0 \mathrm{~cd}$ & & & $19.5 \mathrm{bc}$ & $9.4 \mathrm{a}$ & $13.7 \mathrm{a}$ \\
\hline asal application $58 \mathrm{Kg} \mathrm{K} \mathrm{K}_{2} \mathrm{O} / \mathrm{ha}$ & $90.2 b$ & 91.6abc & $17.2 \mathrm{a}$ & $5 a$ & $22.1 \mathrm{a}$ & $20.7 \mathrm{ab}$ & $4.3 \mathrm{~cd}$ & $5.3 b$ \\
\hline oray $(2 \%)$ at (MT) & $90.2 b$ & 88.0abc & $17.5 \mathrm{a}$ & $17.9 \mathrm{a}$ & $21.2 b$ & $20.6 \mathrm{ab}$ & $6.0 \mathrm{~b}$ & $6.0 \mathrm{~b}$ \\
\hline IT and P.I) & $98.1 \mathrm{a}$ & $94.8 \mathrm{ab}$ & $a b$ & $1 \mathrm{ab}$ & $22.3 \mathrm{a}$ & $8 a b$ & $3.5 \mathrm{~cd}$ & $5.0 \mathrm{bc}$ \\
\hline$(2 \%) a$ & $90.2 b$ & $89.5 a b c$ & 15.2 & $9 \mathrm{ab}$ & $20.1 \mathrm{c}$ & $1 \mathrm{a}$ & $5.0 \mathrm{bc}$ & $5.7 b$ \\
\hline and Bt.) & $97.2 \mathrm{a}$ & $93.0 \mathrm{a}$ & $15.0 \mathrm{ab}$ & $17.3 a b$ & $22.2 \mathrm{a}$ & $22.2 \mathrm{a}$ & $2.8 \mathrm{~d}$ & $3.0 \mathrm{~d}$ \\
\hline$P+1)$ & & 89.3abc & $14.3 \mathrm{ab}$ & $15.5 a b$ & $21.4 \mathrm{ab}$ & 20.2 bc & $4.0 \mathrm{~cd}$ & $3.3 \mathrm{~cd}$ \\
\hline & & $87.0 \mathrm{c}$ & $15.6 \mathrm{ab}$ & $15.5 a b$ & $21.6 \mathrm{ab}$ & $20.0 \mathrm{bc}$ & $3.4 \mathrm{~cd}$ & $5.7 \mathrm{~b}$ \\
\hline F. test & $\star \star *$ & ** & $\star \star \star$ & ** & * & * & ** & ${ }^{* *}$ \\
\hline
\end{tabular}

Means with the same letter are not significant at 0.05 probability level( DMRT).

MT= Maximum tillering stage, $\mathrm{PI}=$ Panicle initiation stage,. Bt= Booting stage

DAH = Days after heading and ERH1 Egyptian Hybrid rice .

\section{Panicle length ( $\mathrm{cm}$ ):}

Duncan's multiple range test showed that a significant difference among potassium treatments against the control in respects to panicle length as listed in Table 2 in both seasons of study, where potassium in case of basal application or foliar sprays application with $2 \% \mathrm{~K}_{2} \mathrm{O}$ at various growth stages showed superiority in panicle length against the control. Among potassium treatments, $\mathrm{K}$ foliar sprays with $2 \% \mathrm{~K}_{2} \mathrm{O}$ at consecutive growth stages, maximum tillering stage, panicle initiation stage and booting stage statistically produced the longest panicle length ( 22.2 and $22.2 \mathrm{~cm}$ ) followed by $\mathrm{K}$ foliar sprays with $2 \% \mathrm{~K}_{2} \mathrm{O}$ at maximum tillering stage and panicle initiation stage ( 22.3 and $20.8 \mathrm{~cm}$ ) in both seasons of study. Whilst, the shortest panicle length was recorded by control $(19.9$ and $19.5 \mathrm{~cm}$ ) in both seasons, respectively. These data are in harmony with that obtained by Cakmak 2005 who reported that when K supply is low, plants can therefore, become very sensitive to environmental stresses. He mentioned also that, improving K-nutritional status of plants greatly minimizes detrimental effects of salinity. 


\section{Sterility percentage ( \% ):}

Data represented in Table 2 asseverated that highly significant differences were obtained among potassium treatments under study regards sterility percentage, where applying $\mathrm{K}$ either through rooting media or foliar sprays over control significantly resulted in reducing sterility percentage in the two studied seasons. Among the potassium treatments, $\mathrm{K}$ foliar sprays with $2 \% \quad \mathrm{~K}_{2} \mathrm{O}$ which was applied thrice at consecutive growth stages, maximum tillering stage, panicle initiation stage and booting stage significantly surpassed the rest foliar of $\mathrm{k}$ sprays application and gave the lowest sterility percentage ( 2.8 and $3.0 \%$ ) followed by $\mathrm{K}$ foliar sprays with $2 \% \mathrm{~K}_{2} \mathrm{O}$ twice at maximum tillering stage and booting stage ( 4.0 and $3.3 \%$ ) in the two studied seasons, respectively. On the other hand, the treatment which did not receive any potassium nutrient gave the highest sterility percentage in both seasons of study. These results also revealed that foliar application of $\mathrm{K}$ at consecutive growth stages of rice plant was better than soil application in case of sterility percentage under saline soil conditions. These results might be ascribed to the fact that potassium absorption by plant leaves is much possible under saline conditions and might be help the plant for regulating stomatal opening and closing.

These data are in agreement with those obtained by Din et al.., 2001. Yang et al.., 2004 reported also that the relative $\mathrm{K}$ concentration in upper and lower leaves at booting and grain filling stages decreased with decreasing $K$ internal use efficiency among the rice genotypes, indicating that $\mathrm{K}$-efficient genotypes had greater $\mathrm{K}$ translocation ability that the $\mathrm{k}$ - inefficient genotypes at low K. Similar results has been detected by Zayed et al.., 2006.

\section{Panicle Characters:}

Data listed in Table 3 demonstrated that a significant difference was obtained among $\mathrm{K}$ foliar sprays application with respects to number of grains/ panicle, panicle weight as well as 1000- grain weight over the control in both seasons of study. Under saline soil conditions, $\mathrm{K}$ foliar sprays with $2 \% \mathrm{~K}_{2} \mathrm{O}$ at physiological consecutive growth stages, maximum tillering, panicle initiation and booting was sufficient to produce the maximum values of number of grains/panicle ( 148.0 and 134.0 ), panicle weight ( 3.7 and $3.7 \mathrm{~g}$ ) and 1000grain weight ( 22.8 and $23.8 \mathrm{~g}$ ) in the two studied seasons, respectively. Data cleared also, that $\mathrm{K}$ application in case of root media statistically gave on par panicle characters values paralleled with the superior $\mathrm{K}$ foliar sprays treatment. Whilst, the rice plants which did not receive any potassium nutrient recorded the lowest panicle characters values mentioned earlier. These data are in agreement with those obtained by Fanaei et al.., 2009 and Quampah et al.., 2011 who revealed that application of $\mathrm{K}$ has been reported to improve the SPAD ( Soil and Plant analysis Difference) value and physiological traits of crop plants then enhance photosynthetic rate which resulted in improving all panicle characters. These data are in agreement with those reported by Zayed, 2002, Wang et al.., 2004 and Bahmaniar, and Ranjbar (2007). 
Table 3: Number of grains / panicle, panicle weight (g) as well as 1000 grain weight $(g)$ as affected by potassium foliar application nutrient at various physiological growth stages for ERH1 under saline soil conditions in 2009 and 2010 seasons.

\begin{tabular}{|c|c|c|c|c|c|c|}
\hline \multirow[t]{2}{*}{ Treatments } & \multicolumn{2}{|c|}{$\begin{array}{c}\text { No of filled } \\
\text { grains/panicle }\end{array}$} & \multicolumn{2}{|c|}{$\begin{array}{c}\text { Panicle } \\
\text { weight }\end{array}$} & \multicolumn{2}{|c|}{$\begin{array}{c}\text { 1000-grain } \\
\text { weight }\end{array}$} \\
\hline & 2009 & 2010 & 2009 & 2010 & 2009 & 2010 \\
\hline $\begin{array}{l}\text { Control } \\
\text { K basal application } 58 \mathrm{Kg} \mathrm{K}_{2} \mathrm{O} / \mathrm{ha} \\
\mathrm{K} \text { spray }(2 \%) \text { at }(\mathrm{MT}) \\
\mathrm{K} \text { spray }(2 \%) \text { at }(\mathrm{MT} \text { and } \mathrm{P} . \mathrm{I}) \\
\mathrm{K} \text { spray }(2 \%) \text { at (MT and } \mathrm{Bt} .) \\
\mathrm{K} \text { spray }(2 \%) \text { at (MT,P.I and } \mathrm{Bt} .) \\
\mathrm{K} \text { spray }(2 \%) \text { at (P.I and } \mathrm{Bt} .) \text {. } \\
\mathrm{K} \text { spray }(2 \%) \text { at (Bt. and } 7 \mathrm{DAH})\end{array}$ & \begin{tabular}{|c|}
$126.7 \mathrm{c}$ \\
$140.9 \mathrm{ab}$ \\
$138.4 \mathrm{ab}$ \\
$142.3 \mathrm{ab}$ \\
$140.8 \mathrm{ab}$ \\
$148.0 \mathrm{a}$ \\
$145.7 \mathrm{a}$ \\
$133.4 \mathrm{~b}$
\end{tabular} & $\begin{array}{c}122.7 \mathrm{~b} \\
132.7 \mathrm{a} \\
122.0 \mathrm{~b} \\
130.0 \mathrm{ab} \\
126.7 \mathrm{ab} \\
134.0 \mathrm{a} \\
127.0 \mathrm{ab} \\
129 \mathrm{ab}\end{array}$ & $\begin{array}{c}3.0 \mathrm{e} \\
3.7 \mathrm{a} \\
3.1 \mathrm{e} \\
3.5 \mathrm{a}-\mathrm{d} \\
3.3 \mathrm{cde} \\
3.7 \mathrm{ab} \\
3.4 \mathrm{bcd} \\
3.6 \mathrm{abc}\end{array}$ & $\begin{array}{c}2.9 \mathrm{~d} \\
3.7 \mathrm{a} \\
3.1 \mathrm{c} \\
3.5 \mathrm{ab} \\
3.3 \mathrm{ab} \\
3.7 \mathrm{a} \\
3.4 \mathrm{ab} \\
3.6 \mathrm{a}\end{array}$ & \begin{tabular}{|c|}
$21.3 \mathrm{c}$ \\
$22.4 \mathrm{ab}$ \\
$21.3 \mathrm{c}$ \\
$22.2 \mathrm{abc}$ \\
$21.4 \mathrm{bc}$ \\
$22.8 \mathrm{a}$ \\
$22.6 \mathrm{a}$ \\
$22.7 \mathrm{a}$
\end{tabular} & $\begin{array}{l}21.6 \mathrm{~cd} \\
22.2 \mathrm{bc} \\
21.2 \mathrm{~d} \\
22.3 \mathrm{ab} \\
21.8 \mathrm{bcd} \\
23.8 \mathrm{a} \\
22.0 \mathrm{bcd} \\
22.7 \mathrm{~b}\end{array}$ \\
\hline F. test & ** & ** & 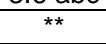 & ** & * & * \\
\hline
\end{tabular}

Means with the same letter are not significant at 0.05 probability level( DMRT).

MT= Maximum tillering stage, $\mathrm{PI}=$ Panicle initiation stage, $\mathrm{Bt}=\mathrm{Booting}$ stage $\mathrm{DAH}=\mathrm{Days}$ after heading and ERH1 Egyptian Hybrid rice.

\section{Grain and Straw yield (t./ha) and Harvest Index:}

Data represented in Table 4 stated that a significant difference was recorded among all potassium treatments used even was root media or foliar application over the control regards grain. Straw yields and harvest index in both seasons of study. The yield data in general revealed that a marked superiority was recorded in all potassium treatments against the control in grain, straw yields and harvest index, where $\mathrm{K}$ as basal application with $58 \mathrm{~kg}$ $\mathrm{K}_{2} \mathrm{O}$ /ha was on par with $\mathrm{K}$ foliar sprays application thrice at maximum tillering stage, panicle initiation stage and booting stage and gave statistically the par grain yield values $(6.13,6.01,6.40$ and 6.23 t/ha $)$, straw yield $(7.62,8.74$, 7.27 and $9.17 \mathrm{t} / \mathrm{ha})$ and harvest index $(0.446,0.410,0.466$ and 0.400$)$ in both studied seasons, respectively.

Table 4 : Grain yield, straw yield ( $t / h a$ ) as well as harvest index as affected by potassium foliar application nutrient at various physiological growth stages for ERH1 under saline soil conditions in 2009 and 2010 seasons.

\begin{tabular}{|c|c|c|c|c|c|c|}
\hline \multirow{2}{*}{ Treatments } & \multicolumn{2}{|c|}{$\begin{array}{c}\text { Grain Yield } \\
(t / h a)\end{array}$} & \multicolumn{2}{|c|}{$\begin{array}{c}\text { Straw Yield } \\
\text { (t/ha) }\end{array}$} & \multicolumn{2}{|c|}{ Harvest Index } \\
\hline & 2009 & 2010 & 2009 & 2010 & 2009 & 2010 \\
\hline Control & $5.06 \mathrm{c}$ & $02 \mathrm{~d}$ & $6.80 \mathrm{c}$ & $8.69 \mathrm{a}$ & $0.426 \mathrm{~b}$ & $0.370 \mathrm{~b}$ \\
\hline $\mathrm{K}$ basal application $58 \mathrm{Kg} \mathrm{K}_{2} \mathrm{O} / \mathrm{ha}$ & $6.13 \mathrm{ab}$ & $6.01 \mathrm{ab}$ & $7.62 \mathrm{ab}$ & $8.74 \mathrm{a}$ & $0.446 \mathrm{ab}$ & $0.410 \mathrm{a}$ \\
\hline K spray $(2 \%)$ at (MT) & $5.60 \mathrm{bc}$ & $5.37 \mathrm{~cd}$ & $7.32 \mathrm{abc}$ & $8.43 \mathrm{ab}$ & $0.430 \mathrm{ab}$ & $0.400 \mathrm{ab}$ \\
\hline K spray $(2 \%)$ at (MT and P.I) & $5.96 \mathrm{ab}$ & $5.81 \mathrm{abc}$ & $7.67 \mathrm{ab}$ & $8.97 \mathrm{a}$ & $0.440 \mathrm{ab}$ & $0.390 \mathrm{ab}$ \\
\hline $\mathrm{K}$ spray $(2 \%)$ at (MT and $\mathrm{Bt}$. & $5.80 \mathrm{~b}$ & $5.59 \mathrm{ab}$ & $6.97 \mathrm{bc}$ & $8.74 \mathrm{a}$ & $0.450 \mathrm{ab}$ & $0.390 \mathrm{ab}$ \\
\hline K spray $(2 \%)$ at (MT,P.I and Bt.) & $6.40 \mathrm{a}$ & $6.23 \mathrm{a}$ & $7.27 \mathrm{abc}$ & $9.17 \mathrm{a}$ & $0.466 \mathrm{a}$ & $0.400 \mathrm{ab}$ \\
\hline K spray $(2 \%)$ at (P.I and Bt.) & & $5.40 \mathrm{~cd}$ & $7.20 \mathrm{abc}$ & $8.41 \mathrm{ab}$ & $0.440 \mathrm{ab}$ & $0.390 \mathrm{ab}$ \\
\hline K spray & 5.0 & & 8.0 & $7.67 \mathrm{~b}$ & 0.3 & $0.420 \mathrm{a}$ \\
\hline F. test & $* *$ & ** & $\star *$ & * & $*$ & $\star$ \\
\hline
\end{tabular}

Means with the same letter are not significant at 0.05 probability level (DMRT).

MT = Maximum tillering stage, $\mathrm{PI}=$ Panicle initiation stage, $\mathrm{Bt}=$ Booting stage, $\mathrm{DAH}=\mathrm{Days}$ after heading and ERH1 Egyptian Hybrid rice.

Data cleared also that no significant difference between $\mathrm{K}$ as foliar sprays application treatments in case of twice or thrice foliar regards grain, 
straw yields and harvest index. Therefore, it could notable that applying $\mathrm{K}$ either through rooting media or foliar sprays over the control significantly increased grain, straw yields and harvest index. This increase in grain and straw yield suggested that the rice yield could be increased under saline soil conditions by $\mathrm{K}$ application (Din et al.., 2001).

From the data obtained, it was notable that grain yield was much affected by $\mathrm{K}$ treatments even was applied through root media or foliar sprays than straw yield under saline soil conditions. Nelson, 1978 and Flower et al.., 1991 reported that the increase in both grain and straw yield might be due to the application of $\mathrm{K}$ in mechanism of stomatal movement, photosynthesis and osmoregulatory adaptation of plants to water stress in saline soils. Similar results has been indicated by Wang et al.., 2004.

Milling characters:

The results obtained indicated that there were a significant superiority in hulling percentage, milling percentage as well as head rice percentage in case of potassium application treatments against the control in both seasons of study as shown in Table 5.

Potassium application significantly increased hulling, milling and head rice percentages. Both of $\mathrm{K}$ as basal application with $58 \mathrm{~kg} \mathrm{~K}{ }_{2} \mathrm{O} / \mathrm{ha}$ and $\mathrm{K}$ as foliar sprays thrice at maximum tillering stage, panicle initiation stage and booting stage were on par regarding hulling, milling and head rice percentages and statistically produced the peak values in both seasons of study.

Therefore, from the data obtained it could be recommended that $k$ application w with $58 \mathrm{~kg} \mathrm{~K} \mathrm{~K}_{2} \mathrm{O} / \mathrm{ha}$ through root media were paralleled with foliar application with $2 \% \mathrm{~K}_{2} \mathrm{O}$ as thrice at maximum tillering stage, panicle initiation stage and booting stage regards all milling characters. Zayed, 2002 ratified similar findings

Table 5: Hulling percentage, milling percentage as well as head rice percentage as affected by potassium foliar application nutrient at various physiological growth stages for ERH1 under saline soil conditions in 2009 and 2010seasons.

\begin{tabular}{|c|c|c|c|c|c|c|}
\hline \multirow{2}{*}{ Treatments } & \multicolumn{2}{|c|}{ Hulling (\%) } & \multicolumn{2}{|c|}{ Milling (\%) } & \multicolumn{2}{|c|}{ Head Rice (\%) } \\
\hline & 2009 & 2010 & 2009 & 2010 & 2009 & 2010 \\
\hline Control & $77.0 \mathrm{c}$ & $78.3 \mathrm{c}$ & $69.7 \mathrm{c}$ & $69.0 \mathrm{c}$ & $61.3 \mathrm{~b}$ & $60.8 \mathrm{c}$ \\
\hline $\mathrm{K}$ basal application $58 \mathrm{Kg} \mathrm{K}_{2} \mathrm{O} / \mathrm{ha}$ & $79.4 \mathrm{a}$ & $80.1 \mathrm{ab}$ & $70.2 \mathrm{c}$ & $71.5 \mathrm{a}$ & $64.1 \mathrm{a}$ & $69.7 \mathrm{a}$ \\
\hline $\mathrm{K}$ spray $(2 \%)$ at $(\mathrm{MT})$ & $79.4 \mathrm{a}$ & $78.3 \mathrm{c}$ & $70.3 \mathrm{bc}$ & $69.3 \mathrm{c}$ & $61.5 \mathrm{~b}$ & $60.0 \mathrm{c}$ \\
\hline $\mathrm{K}$ spray $(2 \%)$ at (MT and P.I) & $80.0 \mathrm{a}$ & $79.9 \mathrm{ab}$ & $72.0 \mathrm{ab}$ & $71.7 \mathrm{a}$ & $62.3 \mathrm{ab}$ & $62.6 \mathrm{~b}$ \\
\hline $\mathrm{K}$ spray $(2 \%)$ at (MT and $\mathrm{Bt})$. & $79.7 \mathrm{a}$ & $79.2 \mathrm{bc}$ & $70.5 \mathrm{bc}$ & $69.7 \mathrm{bc}$ & $61.7 \mathrm{~b}$ & $61.3 \mathrm{c}$ \\
\hline K spray (2\%) at (MT,P.I and Bt.) & $80.0 \mathrm{a}$ & $80.9 \mathrm{a}$ & $72.4 \mathrm{a}$ & $69.7 \mathrm{bc}$ & $61.7 \mathrm{~b}$ & $63.2 \mathrm{~b}$ \\
\hline K spray ( $2 \%)$ at (P.I and Bt.) & $76.8 \mathrm{~b}$ & $78.4 \mathrm{c}$ & $69.0 \mathrm{c}$ & $71.0 \mathrm{ab}$ & $60.2 \mathrm{~b}$ & $61.4 \mathrm{c}$ \\
\hline K spray $(2 \%)$ at (Bt. and $7 \mathrm{DAH})$ & $80.2 \mathrm{a}$ & $80.8 \mathrm{a}$ & $70.1 \mathrm{c}$ & $71.0 \mathrm{ab}$ & $61.3 b$ & $63.7 \mathrm{ab}$ \\
\hline F. test & * & $\star \star$ & * & $\star \star$ & $*$ & * \\
\hline
\end{tabular}

Means with the same letter are not significant at 0.05 probability level (DMRT).

MT = Maximum tillering stage, $\mathrm{PI}=$ Panicle initiation stage, $\mathrm{Bt}=$ Booting stage, $\mathrm{DAH}=$ Days after heading and ERH1 Egyptian Hybrid rice.

Nitrogen Content (\%), Protein content(\%) and Moist Content (\%):

Nitrogen concentration in rice grain changed according to potassium treatments because of synergetic relationship between $\mathrm{N}$ and $\mathrm{K}$. When $\mathrm{K}$ 
concentration in rice plants increased $\mathrm{N}$ concentration directly increased. Duncan's multiple range test asseverated that $\mathrm{k}$ application even was applied through root media as basal with $58 \mathrm{~kg} \mathrm{~K}_{2} \mathrm{O} / \mathrm{ha}$ or foliar sprays thrice along with natal growth stages surpassed the control in grain nitrogen content ( GNC ), grain protein content ( GPC ) and moist content ( GMC ) as listed in Table 6. The highest GNC and GPC were recorded when $\mathrm{K}$ was used as foliar sprays with $2 \% \mathrm{~K}_{2} \mathrm{O}$ thrice at maximum tillering stage, panicle initiation stage and booting stage $(1.68,1.76,10.03$ and $10.15 \%)$ followed by $K$ foliar sprays with $2 \% \mathrm{~K}_{2} \mathrm{O}$ twice at maximum tillering stage and panicle initiation stage $(1.50,1.74,8.92$ and $10.39 \%)$ in both seasons of study, respectively.

Table 6: Nitrogen content, protein content as well as most content in grains as affected by potassium foliar application nutrient at various physiological growth stages for ERH1 under saline soil conditions in 2009 and 2010 seasons.

\begin{tabular}{|c|c|c|c|c|c|c|}
\hline \multirow[t]{2}{*}{ Treatments } & \multicolumn{2}{|c|}{ Nitrogen (\%) } & \multicolumn{2}{|c|}{ Protein (\%) } & \multicolumn{2}{|c|}{ Most (\%) } \\
\hline & 2009 & 2010 & 2009 & 2010 & 2009 & 2010 \\
\hline Control & $1.36 \mathrm{~b}$ & $1.36 \mathrm{c}$ & $8.13 \mathrm{~b}$ & $8.09 \mathrm{c}$ & $6.95 \mathrm{abc}$ & $8.24 \mathrm{~b}$ \\
\hline $\mathrm{Kg} \mathrm{K}_{2} \mathrm{O} / \mathrm{ha}$ & $1.53 \mathrm{ab}$ & $1.54 \mathrm{abc}$ & $9.14 a b$ & $9.18 \mathrm{abc}$ & $7.20 \mathrm{abc}$ & $8.09 \mathrm{~b}$ \\
\hline$y(2 \%)$ & 1.51 & $1.47 \mathrm{bc}$ & $8.98 a b$ & $8.74 \mathrm{bc}$ & $7.31 \mathrm{ab}$ & $8.42 \mathrm{ab}$ \\
\hline K spray $(2 \%)$ a & $1.50 \mathrm{ab}$ & $1.74 \mathrm{a}$ & $8.92 a b$ & $10.39 \mathrm{a}$ & $6.85 \mathrm{bc}$ & $8.50 \mathrm{ab}$ \\
\hline K spray $(2 \%)$ & $1.53 \mathrm{ab}$ & $1.60 \mathrm{ab}$ & $9.14 a b$ & $9.56 \mathrm{ab}$ & $7.41 \mathrm{a}$ & $8.49 a b$ \\
\hline $\mathrm{K}$ spray $(2 \%)$ at (MT,P.I and Bt.) & $1.68 \mathrm{a}$ & $1.76 \mathrm{a}$ & $10.03 \mathrm{a}$ & $10.15 a b$ & $7.08 \mathrm{abc}$ & $8.21 \mathrm{~b}$ \\
\hline K spray $(2 \%)$ at (P.I and Bt.) & $1.38 \mathrm{~b}$ & $1.76 \mathrm{a}$ & $8.21 \mathrm{~b}$ & $10.51 \mathrm{a}$ & $7.16 \mathrm{abc}$ & $8.35 a b$ \\
\hline $\mathrm{K}$ spray $(2 \%)$ at (Bt. and $7 \mathrm{DAH})$ & $1.45 \mathrm{ab}$ & $1.47 \mathrm{bc}$ & $8.63 \mathrm{ab}$ & $8.74 \mathrm{bc}$ & $6.84 \mathrm{c}$ & $8.80 \mathrm{a}$ \\
\hline F. test & & & & & & \\
\hline
\end{tabular}

Means with the same letter are not significant at 0.05 probability level (DMRT).

MT= Maximum tillering stage, $\mathrm{PI}=$ Panicle initiation stage, $\mathrm{Bt}=$ Booting stage, $\mathrm{DAH}=\mathrm{Days}$ after heading and ERH1 Egyptian Hybrid rice.

Grain shape:

Data shown in Table 7 revealed, that potassium application significantly improved rice grain shape of Egyptian hybrid rice one over the control treatment. Where, $\mathrm{k}$ foliar sprays application twice or thrice at natal growth stages surpassed $\mathrm{K}$ application as basal with grain shape concern. Among $\mathrm{K}$ foliar spray schedules of application, $\mathrm{k}$ foliar sprays with $2 \% \mathrm{~K}_{2} \mathrm{O}$ at booting stage and one week after heading statistically gave the peak values of grain shape ( 3.30 and 3.38 ) followed by $\mathrm{K}$ foliar sprays with $2 \% \mathrm{~K}_{2} \mathrm{O}$ thrice ( 3.24 and 3.29 ) in both seasons, respectively. Whilst, the treatment which did not receive any potassium nutrient recorded the lowest grain shape values ( 3.10 and 3.05 ) without any significant difference with $\mathrm{K}$ in case of basal application in both seasons of study. The acceptable grain shape was produced by the potassium treatment of K spray (2\%) at (MT and Bt.). Similar results were reported by Wang et al. 2004

Amylose content (\%) and Oil Content (\%):

Multiple range test showed that there were highly significant differences among all potassium treatments used either as basal or foliar sprays application at natal growth stages of rice plants and surpassed the control in amylose content and oil content as shown in Table (7). Among potassium treatments, $\mathrm{K}$ foliar sprays with $2 \% \mathrm{~K}_{2} \mathrm{O}$ thrice at maximum tillering $\mathrm{g}$ stage, panicle initiation stage and booting stage recorded the 
highest amylose and oil contents and the lowest values of amylose content in both seasons of study, respectively. Data obtained revealed also that $\mathrm{K}$ foliar sprays with $2 \% \mathrm{~K}_{2} \mathrm{O}$ twice at panicle initiation stage and booting stage came in the next (21.08, 20.87, 7.09 and 7.33 ) regards amylase and oil contents in both seasons, respectively.

Therefore, it could be concluded that $\mathrm{K}$ foliar sprays with $2 \% \mathrm{~K}_{2} \mathrm{O}$ thrice at consecutive growth stages started from maximum tillering stage until booting stage was much sufficient to get the highest grain shape, amylase content and oil content in hybrid rice cultivar under saline soil conditions. Wang et al. 2004, Bahmaniar, and Ranjbar (2007) came to similar results.

Table 7: Grain shape, amylose content as well as oil percent as affected by potassium nutrient foliar application at various physiological growth stages for ERH1 under saline soil conditions in 2009 and 2010 seasons.

\begin{tabular}{|c|c|c|c|c|c|c|}
\hline \multirow{2}{*}{ Treatments } & \multicolumn{2}{|c|}{ Grain shape } & \multicolumn{2}{|c|}{ Amylose \% } & \multicolumn{2}{|c|}{ Oil \% } \\
\hline & 2009 & 2010 & 2009 & 2010 & 2009 & 2010 \\
\hline Control & $3.10 \mathrm{bc}$ & $3.09 \mathrm{~d}$ & $20.95 \mathrm{a}$ & $20.85 \mathrm{a}$ & $4.52 \mathrm{f}$ & $4.21 \mathrm{~d}$ \\
\hline $\mathrm{K}$ basal application $58 \mathrm{Kg} \mathrm{K}{ }_{2} \mathrm{O} / \mathrm{ha}$ & $3.12 \mathrm{bc}$ & $3.15 \mathrm{~cd}$ & $19 . .93 \mathrm{~b}$ & $19 . .6 \mathrm{~d}$ & $5.81 \mathrm{~d}$ & $5.48 \mathrm{c}$ \\
\hline $\mathrm{K}$ spray $(2 \%)$ at $(\mathrm{MT})$ & $3.15 \mathrm{bc}$ & $3.22 \mathrm{bc}$ & $20.27 \mathrm{~d}$ & $19.87 \mathrm{~d}$ & $4.84 \mathrm{e}$ & $4.33 \mathrm{~d}$ \\
\hline $\mathrm{K}$ spray $(2 \%)$ at (MT and P.I) & $3.18 \mathrm{abc}$ & $3.22 \mathrm{bc}$ & $21.08 \mathrm{~b}$ & $20.62 \mathrm{bc}$ & $6.41 \mathrm{c}$ & $6.49 \mathrm{~b}$ \\
\hline $\mathrm{K}$ spray $(2 \%)$ at (MT and Bt.) & $3.08 \mathrm{c}$ & $3.07 \mathrm{ab}$ & $20.38 \mathrm{~cd}$ & $20.23 \mathrm{~cd}$ & $5.70 \mathrm{~d}$ & $4.46 \mathrm{~d}$ \\
\hline $\mathrm{K}$ spray $(2 \%)$ at (MT, P.I and Bt.) & $3.24 \mathrm{abc}$ & $3.29 a b$ & $18.71 \mathrm{~d}$ & $18.31 \mathrm{~d}$ & $7.76 \mathrm{a}$ & $7.25 \mathrm{a}$ \\
\hline K spray (2\%) at (P.I and Bt.) & $3.26 a b$ & $3.28 \mathrm{ab}$ & $21.08 b$ & $20.87 \mathrm{ab}$ & $7.09 \mathrm{~b}$ & $7.33 \mathrm{a}$ \\
\hline $\mathrm{K}$ spray $(2 \%)$ at (Bt. and $7 \mathrm{DAH})$ & $3.30 \mathrm{a}$ & $3.38 \mathrm{a}$ & $20 . .9 \mathrm{a}$ & $20 . .90 \mathrm{a}$ & $7.31 \mathrm{~b}$ & $5.31 \mathrm{c}$ \\
\hline F. test & * & $\star *$ & $\star \star$ & ** & $\star \star$ & $* *$ \\
\hline
\end{tabular}

Means with the same letter are not significant at 0.05 probability level (DMRT).

MT= Maximum tillering stage, $\mathrm{PI}=$ Panicle initiation stage, $\mathrm{Bt}=$ Booting stage, $\mathrm{DAH}=\mathrm{Days}$ after heading and ERH1 Egyptian Hybrid rice.

\section{Conclusion}

Finally, from the data obtained it could be concluded that $\mathrm{K}$ foliar sprays with $2 \% \mathrm{~K}_{2} \mathrm{O}$ thrice at natal growth stages; maximum tillering stage, panicle initiation stage and booting stage is much sufficient to improve yield and yield components as well as physiological properties of Egyptian hybrid rice under saline soil conditions.

\section{RERERENCES}

A.O.A.C Association of Official Analytical Chemists (1990). Official methods of analysis Association of Official Analytical Chemists. Washington. D.C.,USA .

Bahmaniar, M.A. and G.A. Ranjbar (2007) Response of rice (Oryza sativa,L.) Pakistan J. of Bio. Sci.10 (11):1880-1884.

Cakmak, I. (2005). The role of potassium in alleviating detrimental effects of a biotic stresses in plants. J. Plant Nutr. Soil Sci. 168, $521-530$.

Dibb, D. W. and W. R. Thompson. (1985). Interaction of potassium with other nutrients. PP: 515- 532. In Potassium in agriculture. Amer Soc. Agron. Crop Sci. Soc. Amer and Soil Sci. Soc. Amer Madison,WI.

Din, C., S. M. Mehdi., M. Sarfraz., Ghulam Hassan and M. Sadiq, (2001). Comparative efficiency of foliar and soil of $\mathrm{K}$ on salt tolerance in rice. Pakistan J.of Bio. Sci. 4 (7): 815- 817. 
Fanaei, H. R., M. Galavi., M. Kafi and A.G. Banjar, (2009). Amelioration of water stress by potassium fertilizer oil seed species. Int. J. Plant Prod., 3:41- 54

Flower, T. J., M.A. Hajibugheri and A. R. Yeo (1991). Ion accumulation in the cell walls of rice plants growing under saline conditions. Evidence for the oertli hypothesis .Plant Cell and Env.

Gomez, K. A. and A. A. Gomez (1984). Statistical procedures for Agriculture Research, edn2. International Rice Research Institute, Manila, Philippines.

Gorgy, R.N, B.A.Zayed and A.A.Abou Khalifa (2009) Effect of split application of nitrogen and potassium to SK2034H hybrid rice. J.of Agric. Sci. Mansoura Univ., 34(11):10631-10642

Juliano B.O. (1971). A simplified assay for milled rice amylose Cereal .Sci .Today 16: 334-338, $340-360$.

Khush, G.S; C.M. Paule and N. M. Dela-Cruze (1979) . Rice grain quality evaluation and improvement at IRRI, Workshop on chemical aspects of rice grain quality. IRRI. Manila, Philippines.

Liu, J. X., X.E. Yang, Y. A. Yang and L. H. Wu. (2003). Some agronomic and nutritional characteristics for potassium- efficient rice genotypes under low potassium stress. Plant Nutr. Fert. Sci., 9: $190-195$.

Marschner, H.(1995). Mineral Nutrition of higher plants. $2^{\text {nd }}$ ed., Academic Press, San Diego, USA.

Nelson, W.L. (1978). Influence of K on tolerance to stress.( North American Experience ). P: 203-211.In G.S. Sekhon (Ed.) Potassium in soils and Crops. Potash Res. Inst. of New Delhi.

Qader, A. (1998). Alleviation of sodicity stress on rice genotypes by phosphorus and potassium fertilization .Plant and Soil, 203(2), 269277.

Quampah Alfred, Ren-Ming wang, Imran Haider Shamsi, Ghulam Jilan, Qiao Zang, Shuijin Hua and Haiming Xu. (2011). Improving water productivity by potassium application in various rice genotypes. Int. J. Agric. Biol., $13: 9-17$.

Ramos, D. C., J. P. Descalsota and G. O. Senvalentin. (1999). Efficiency of foliar application of mono potassium phosphate. Terminal Report Submitted To The Funding Agency, ROTEM AMFERT NEGEV, by Phil Rice, Philippines

Waller, R.A. and D.B. Duncan. (1969). Base rule comparison symmetric multiple comparison proplem. Amer - stat Assoc. J. 1485-1503.

Wang, Q.S.,Z.R.Hong,D.Y.Feng,J.Z.Jun,C.W.xing and H.P.Sheng(2004). Effect of potassium fertilizer application raters on plant potassium accumulation and grain quality of japonica rice. Scientia Agric. Sinica, 37(10)1444-1450.

Yang, X. E., H. Li, G.J. D. Krik and A. Dobbermann (2005). Room-induced changes of potassium in the rhizosphere of lowland rice. Common Soil Sci. Plant Anal., 36: 1947-1963.

Yang, X. E., J. X. Lin., W. M. Wang., Z. Q. Ye and A. C. Luo (2004). Potassium internal use efficiency relative to growth vigor, potassium distribution, and carbohydrate allocation in rice genotypes. J. of Plant Nutrition. 27(5): $837-852$. 
Zayed, B. A.(2002) Performance of Some Rice Cultivars as Affected by irrigation and potassium treatments under saline soil.PhD thesis, dept. of agron., Fac. of Agric. Mansoura Univ., Egypt.

Zayed B.A.:A.A.EL-Gouhary , A.M.El-Ekhtyar and S.E.M. Sedeex (2006): Response of Giza 177 and SK2034H to potassium splitting .First Filed Crop Con., 22-24, Agust .Giza ,Egypt:407-414.

Zayed, B. A. W. M. EL-Khoby, S.M. Shehata and M.H. Ammar (2007). Role of potassium application on the productivity of some inbred and hybrid rice varieties under newly reclaimed saline soils. African Crop Con. Proceedings. 8: $53-60$.

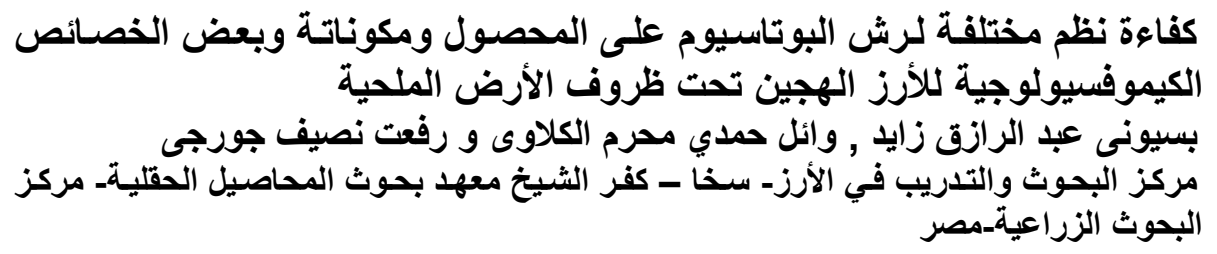

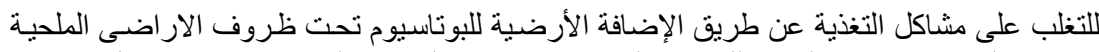

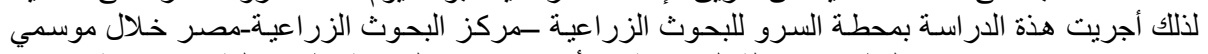

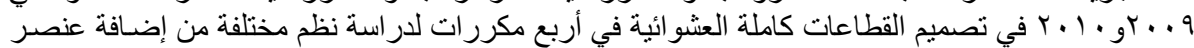

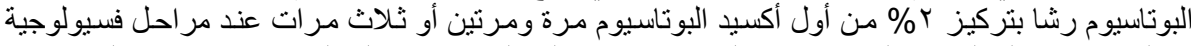

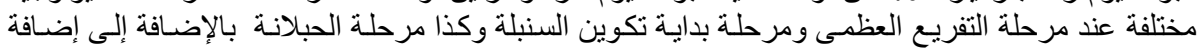

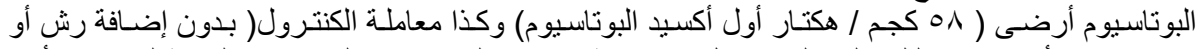

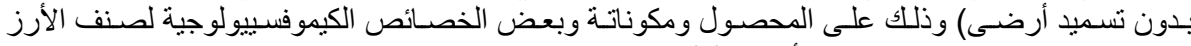
هجين مصري واحد تحت ظروف الك الأرض الملحية.

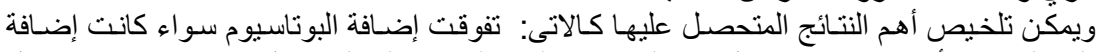

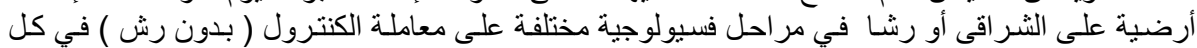

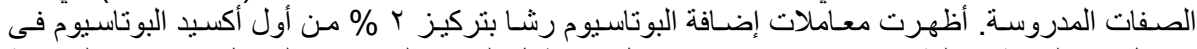

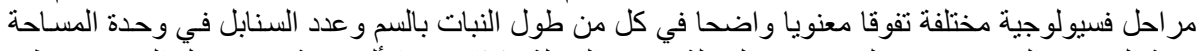

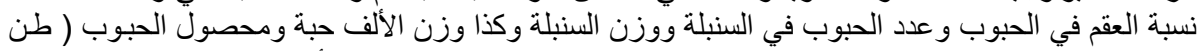

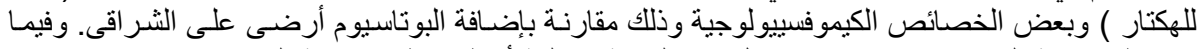

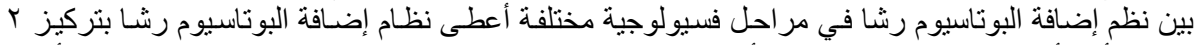

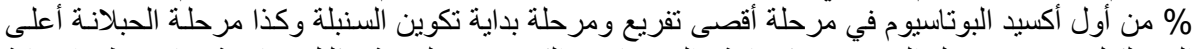

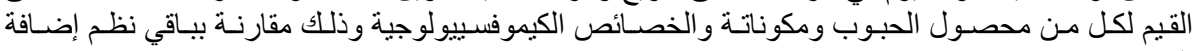

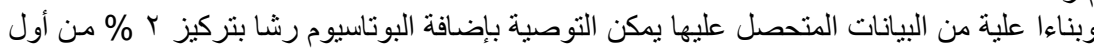

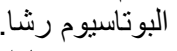

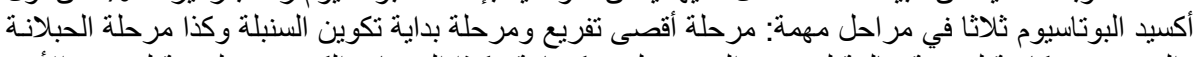

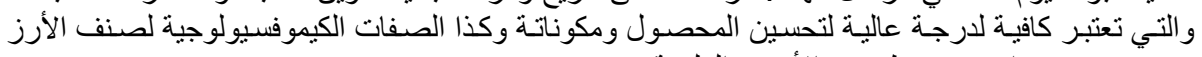
هجين مصري واحد تحت ظروف الأرض الملحية.

كلية الزراعة - جامعة المنصورة كلية الزراعة - جامعة كفر الثيخ

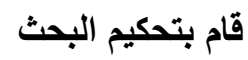

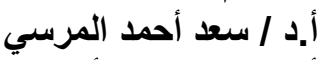

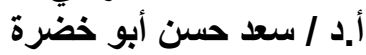

